\title{
Application of the Finite Element Method to a microzonation study of the Salonica Region
}

\author{
A. A. Rolssopollos $(*)-$ C. A. Srrmatiezis $(* *)$ \\ Received on June $1 \overline{5}$ th, 1973
}

\begin{abstract}
Sumary. - The main olject of the present paper is an attempit to present a model for the estination of the groum movements during an tarthguake, nsing the Finite Element Method, Some preliminary results for the subsoil of the saloniea region are subseguently calculated, using this model, accorting to the existing geological and seismological data of the region. Finally, some general eonclusions are derived.
\end{abstract}

Rrassunto. .-. Scopo prineipale di questo lavoro ì un tentativo di presentare un modello per la valutazione tei movimenti del suolo durante un terremoto usufruendo del Hetodo dell'Elemento Finito. Lsando quest'nltimo etl in base ai dati geologici e sismici gia esistenti, si sono prima caleolati alcuni risultati per il sottosuolo della regione di Salonicco traen. done, infine, alcune conclusioni di carattere generale.

\section{1. - IntRodiction}

Among the various exjsting definitions, Mlicrozoning can be rlefined as the sturly of small land areas under local geology conditions amd eartliquake characteristies, serving as a guide for safer land use and safer construction, according to the specified local diflerences in enthquake attack on structures.

In November 1971 during the first mecting of the working group on Hicrozoning in Belgrade, Salonica was chosen as a site for the Pilot Yicrozoning study accorling to the plan of operation of the UNTOP. UNESCO Project for the seismicity of the Balkan Region.

(*) Civil Eng. LNESCO Project on the seisuicity of the Balkan Region. National Technical I'niversity of Athens.

(**) Dr. Civ, Eng, Lecturer, Institute of Structural Analysis and Aseisnic Research. National Technical Lniversity of $\Lambda$ thens. 
The purpose of the present pajer on Microzonation is an attempt by the authors to present a model for the estimation of the ground movements during an earthquake, using the Finite Element Methorl. Using this model, some earthquake claracteristics of the subsoil of Salonica are subsequently calculated according to the existing geological ant seismological tlata for the region ant some general conclusions are derived, as a contribution to the UNIPP-UNESCO Programme.

The main idea of the morlel proposed in this paper was discussed during the "Seminar on Microzonation" lield by UNESCO in Thessaloniki, on $A$ joril $9-13,1973$.

\section{2. - Model Charioteristios}

For the development of the model, an elastic layer of uniform thickness $H$ and width equal to unity is considered, based on the bedrock (sublayer) which is assumed to be plane (Fig. 1).

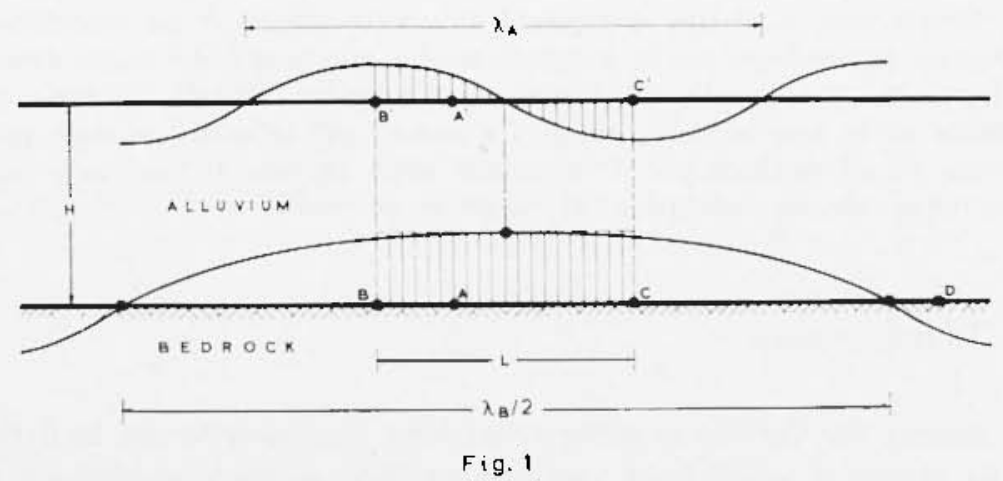

The present sturly is concentrated on the eftects due to shear waves whicl are of primary importance in the microzoning problem. Moreover it is assumel that the tlirection of wave projagation in the rock is irrelevant and so the bedrock is translaterl botlily. Thougl, the motion of the berlock surface between points $B$ and $C$ is assimed as a rigid body motion and the acceleration is taken constant along the surface $B C$ of the bedrock. This is possible as the wave length $\lambda_{B}$ in the berrock is exjected to be mucl greater than the wave lengtl $\lambda_{A}$ in alluvium (Fig. 1). 
It is also assumed that the main contribution for the excitation of soil at a point $A^{\prime}$ (Fig. 1) of the surface is from the region $B-C$ of length $L$. Points out of the region $B-C$, such as point $D$, have not signifieant effect on point, $A^{\prime}$ since the energy at $D$ will be refracterl at the rock-soil interface and propagated vertically. For the purpose of detemining the displacements of the ground surface during the earthquake the lenght $L$ is taken as a varying parameter.

During the present study the distribution of acceleration along the height of the alluvinm for the region $B$ - $C$ considered is assumed parabolic with a law of distribution:

$$
\varepsilon(x, y)=\varepsilon_{o}+c(x) \cdot y^{i}=\varepsilon_{o}+\varepsilon_{A}
$$

where $c(x)$ is a function of $x$.

In the above expression the first term $\varepsilon_{o}$ is the constant accelerartion of the alluvium layer due to the bedrock movement. The second term $\varepsilon_{A}=c(x) y^{2}$ describes the acceleration at each point of the alluvium layer, due to relative movement of the layer to the bedrock.

A cosinusoirlal distribution of accelerations along the length of the layer:

$$
\varepsilon_{A}=h(y) \cos \frac{2 \pi}{\lambda_{A}} x
$$

is assumed with $\Pi(y)$ varying from zero at the bedrock surface to its maximum value at the ground surface. This maximum value is the difference between the maximum accelerations at the ground surface and the bedrock surface. On fig. 2 this cosinusoidal distribution of

SECTIONS:
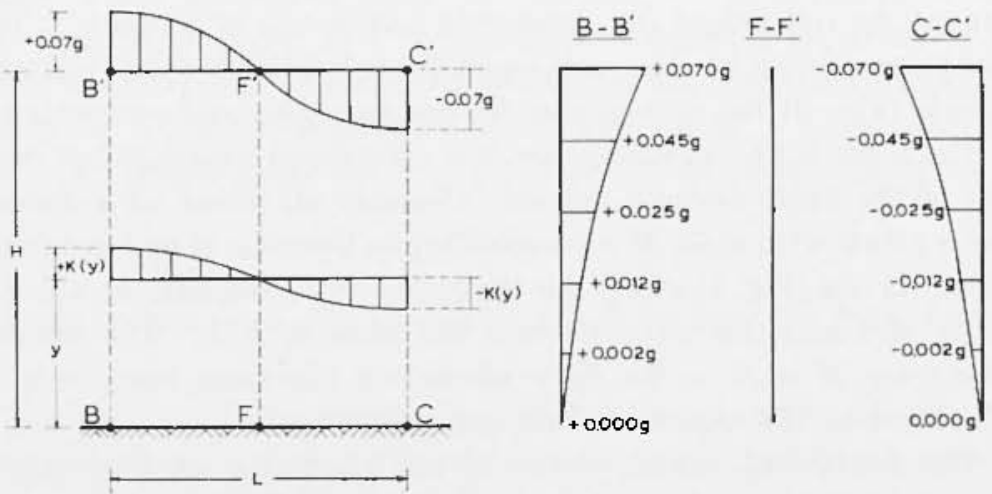
accelerations is shown for the subsoil of Salonica considered in the present paper, for which the ground surface acceleration and the betlrock surface acceleration are found equal to $0.17 \mathrm{~g}$ and $0.10 \mathrm{~g}$ respectively, as slown in the next paragraphs.

Juring the present study a section $B C^{\prime} C^{\prime \prime} B^{\prime}$ of the layer is consirlered at a moment where the cosimusoidal acceleration wave las the shape of fig. 2 . The separation of this section is permitted because the axes $C C^{\prime \prime}, B B^{\prime}$ are axes of antimetyy of loaling and so no horizontal forces act along them after separation.

For the tletermination of the characteristics of the ground movements, the Finite Element Methor is applied (12). A suitable computer programme was used for the case considered.

The surface of the layer examined of lengtl $L$ and heiglit $H$ is divisled by horizontal and verticul lines into equal rectangular wements



of lenght $\Delta x$ and height $A y$, orrered in $l$ lines and $m$ rolumns. Tlese rectangular elements are subsequently subdivided into triangruar elements (Fig. 3) for convenience of programming and computing.

The mass of the examinet layer is consitlered concentrated on the joints of the finite element system. Namely all joints are consitleret as mass points with mass $M$ corresponding to the mass of one rectanguar element $\Delta x \cdot \Delta y$ (Fis. 3 ) except for the joints of the bounlaries wlere the mass is $M / 2$ and the corners where the mass is $M / 4$. The weight $B$ of the mass $M$ is $B=A x \cdot A y \cdot \gamma$ where $\gamma$ is the mean specific weight of the layer at the region of the joint consislered.

The lorizontal seismic force arting statically on each joint is $H=\varepsilon(x, y) B$ where $\varepsilon(x, y)$ is the function tescribing the dist ribution of the seismic acceleration over the surface of the layer. 


\section{3. - SFISHICTTY OF THE TRETION}

The uban area of Salonica is not aseismie. Many sbrong enrthquakes have shaken the region with destructive results in the past. The most destructive earthquake for the city of Salonica seems to have been the shock of July 5,1902 with maximum intensity VIII-IX of the Mercalli-Sieberg soule.

The maximum intensity observer in the area of Salonica over the period $1800-1972$ is, according to the existing map of isolines of maximum intensities of the region, IX rlegrees of the Berealli seale.

Arcorling to the empirical formula for the ground seismic aceoleration $a_{g}$ for the region of Greece:

$$
a_{y}=0.26-0.1 \cdot I+0.01 \cdot I^{2}
$$

where $I$ is the Maximum expected intensity of the MLercalli scale, the maximum aceeleration expected at the ground surfare for tho region of Salonica is $0.17 g$.

The predominant period $T$ of an expected earthquake is given by the formula:

$$
\log T=0.26 M-1.32
$$

given by muramutsu (1966) and found equal approximately to $0.40 \mathrm{sec}$, for a maguitude $M=6.5$.

Salonica is near in the center of the area bounded by the parallek $40^{\circ} \mathrm{N}-410 \mathrm{~N}$ and the meriflians $22.5 \mathrm{wE}-23.50 \mathrm{~F}$. The nearest foci around Salonica which genorated large earthquakes are at distances $15 \mathrm{~km}$ $30 \mathrm{~km}$, but the stronger near testructive earthquakes are from $60 \mathrm{~km}$ epicentral distances. The return periods for shallow shocks which occured in the region of Salonica are $18-23$ years for $M=5.5,45-55$ years for $M=6,110-135$ years for $M=6,5$, and $275-335$ years for $M=7\left(^{3}\right)$.

\section{4. - GFOTOGICAL AND TECTOXIC OHARACTEIRISTCS OF THE REGTON}

The subsoil of the region of Saloniea is not homogeneous and varies from place to place. Alluvium consolidated sand flunes, granitic metamorplies ete, are the usual types of soil which compose the subsoil of the region. 
The surface layer may be assumed to have a mean thickuess of $20 \mathrm{~m}$ above the bedrock. Tn Fig. 4 are shown some typical boreloos of the region of Salonica. From these characteristic borcholes and
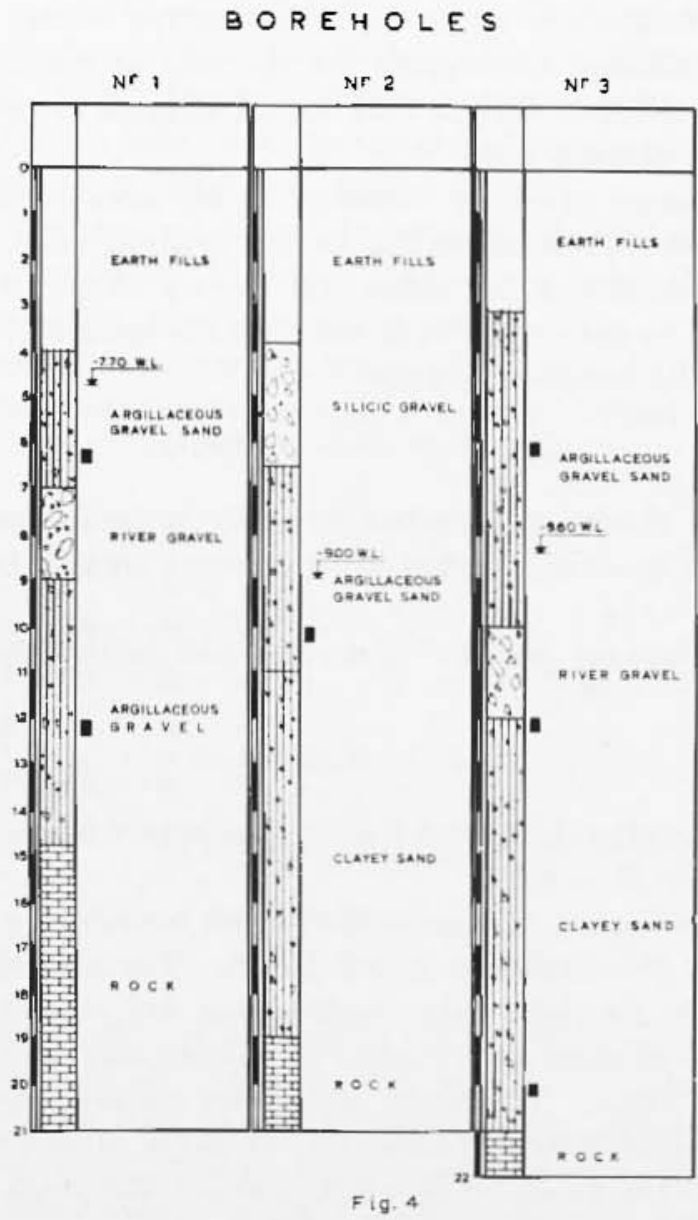

others existing we can also accejt an average water level at a depth of $8 \mathrm{~m}$.

Although the mechanical characteristics of the surface layer may vary from place to place, the small quantities of the existing sand, permit us to consider the layer during the present preliminary study as alluvium. 
The claracteristics of this alluvium are estimated as following:

Below the water level the alluvium is completely saturated ant the specilic woight is given by the formula: $\gamma=\gamma_{s}-n\left(\gamma_{s}-\gamma_{w}\right)$ where $n$ is the purosity, $\gamma_{s}$ is the specifie woight of the solid particles, and $\gamma_{w}$ is the specific woight of the water. For the values of $\gamma_{s}=2.75$, $n=0.40$ and $\gamma_{a}=1$, the value of the saturated specilie weight of the layer is found $\gamma=2.051 / \mathrm{m}^{3}$. Above the water level the allurium is partly saturated and the existing measurements slow a mean valne of $\gamma=1.80 \mathrm{t} j \mathrm{~m}^{3}$.

The laboratory tests from examined specimens slowed a quite satisfactory strengtl permitting $n$ s to aceept a modulus of elasticity $E=300 \mathrm{~kg} / \mathrm{em}^{2}$. The Poisson's zatio is taken equal to the value $y-0.45$.

Finally, the velucity of stwares in the allurium is assumed equal $10 v_{s}=0.25 \mathrm{~km} / \mathrm{sec}$.

The aforementioned alluxium deposit is considered to be strong enumgl enabling the application of the elastic theory and microtremor techuiques.

Aecorting to the existing greologieal slata, the bedrock of the region of Salonicu consists mainly of linestones and marbles. The mechanical characteristics of limestome are density $\varrho=2.30$, modulus of elasticity

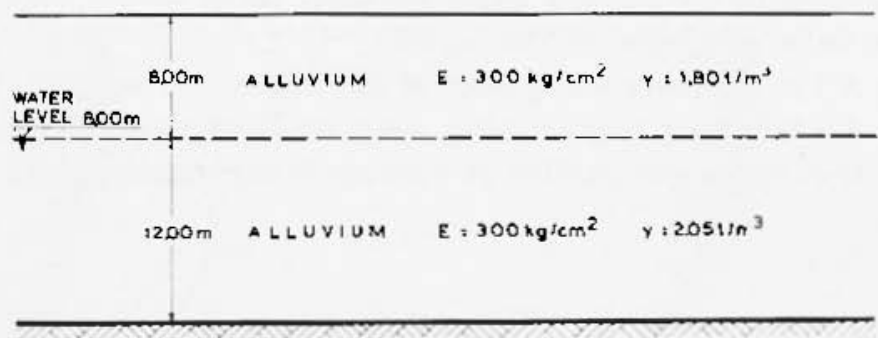

BEDROCK

Fig. 5

$E=83.4 \times 10^{10} \mathrm{~kg} / \mathrm{cm}^{-}$and of marble $\omega=2.30, E=37.5 \times 10^{10} \mathrm{~kg} / \mathrm{cm}^{2}$. The ligh values of the morlulus of elasticity are the to the small deformability of the rock.

The velocities $r_{p}$ of the dilatational $P$-waves and $r$ of the distortional $\$$-waves are estimaterl for the bedrock of the region of Salonica equal to $v_{p}=2.5 \mathrm{~km} / \mathrm{sec}, v_{s}=1.0 \mathrm{~km} / \mathrm{sec}$. These values are approxi- 
mate estimations, since there are no yet accurate measurements of the wave veloeities of the region.

As mentioned before the maximum acceleration on the ground surface is ealeulated accorling to the existing data, for an intensity $I=\mathrm{IX}$ and found equal to $0.17 \mathrm{~g}$.

The corresponding intensity $I_{0}$ at the surface of the bedrock is calculated from the Medvedev formula $\left({ }^{\circ}\right)$ :

$$
I_{0}=I-\Delta I
$$

where $I$ is the surface intensity and $\Delta T$ is given by the expression:

$$
\Delta I=\Delta I_{a}+\Delta I_{w}=1.67 \log \left(\frac{\gamma_{o} v_{o}}{\gamma_{1} v_{1}}\right)+v \cdot e^{-0.04 h^{2}}
$$

where $\gamma_{o} v_{o}$ and $\gamma_{1} v_{1}$ are the values of seismic impedance or rigidity for the bedrock and the alluvium respectively, $h$ is the deptl of the water level in meters and $y$ is a constant coefficient taken equal to 0.8 for the region considered. For the values $\gamma_{1}=2.0 \mathrm{t} / \mathrm{m}^{3} v_{1}=0.25 \mathrm{~km} / \mathrm{sec}$ $\gamma_{o}=2.30 \mathrm{t} / \mathrm{m}^{3}, v_{o}=1.0 \mathrm{~km} / \mathrm{sec}$ and $h=8.0 \mathrm{~m}$, we have that $\Delta I=I$ and hence $I_{0}=$ VIII, corresponding to a bedrock surface acceleration equal to $\varepsilon_{0}=0.10 \mathrm{~g}$. This approximate value for the berlrock acelerition is used in the present paper because, there are no other, more accurate data, available for the region.

From the seismotectonic map of the region of Salonica we can observe the following zones having common borders: a) post-tectonie deposit; b) complex geosyncline of Vardar; c) Serbomacedonian massif (Rilge).

\section{5. - Restras - Conchusions}

Four cases of free zones of a depth $20 \mathrm{~m}$ are considered witl values of the parameler $L$ equal to $25 \mathrm{~m}, 50 \mathrm{~m}, 75 \mathrm{~m}, 100 \mathrm{~m}$, respectively.

The steps $\Delta x, A y$ along the axes ox, oy are taken equal to fom and $4 \mathrm{~m}$ respectively for all cases.

In Figs. $6 a, 6 b, 6 c, 6 d$ the horizontal relative to the berlrock displacements $\delta_{x}$ along the depth $d$ of the alluvium layer considered are shown. Namely, for each case of length $L$, the horizontal flisplacements along vertieal sections of the alluvium layer, taken every 5m, are presented. The ordinates $x$ of each section are written on the corresponding curve. 
$\underline{L}=25 \mathrm{~m}$

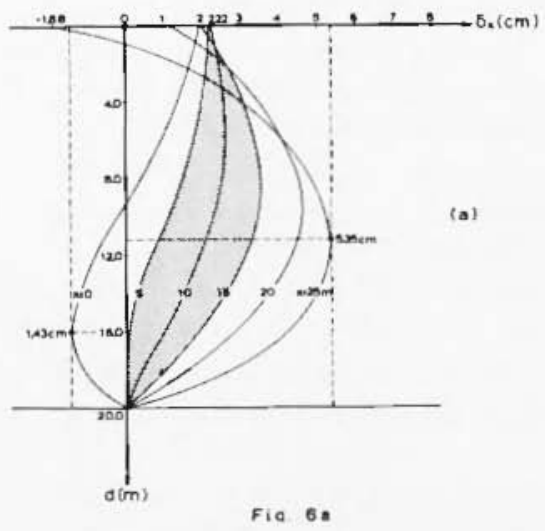

$\underline{L}=75 \mathrm{~m}$

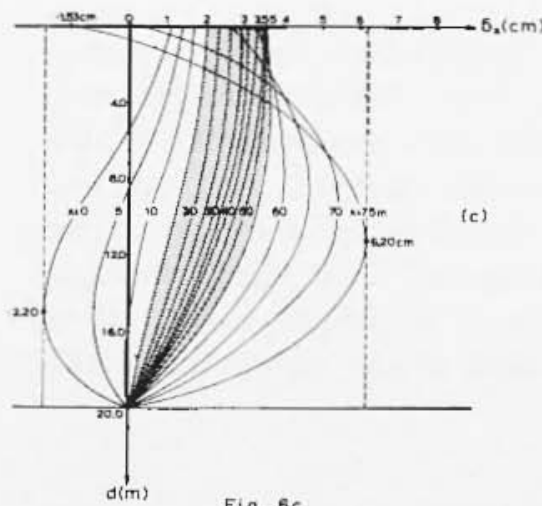

Fig. $6 \mathrm{c}$
$\underline{L}=50 \mathrm{~m}$

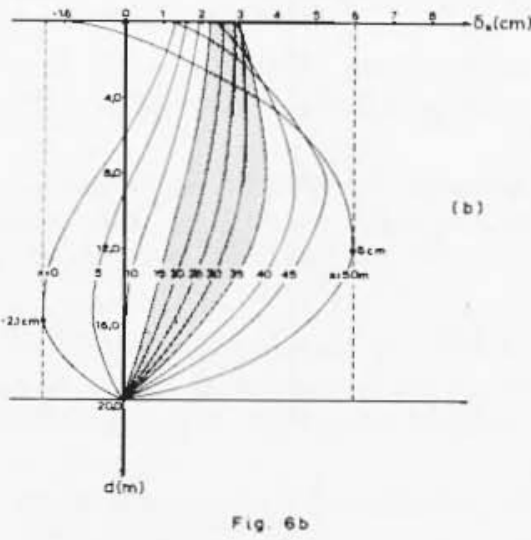

$\underline{\mathrm{L} .100 \mathrm{~m}}$




In Jig. $\tau$ the variation of the horizontal displacements $\delta_{x}$ with the lengtli $L$ is slown for the ground surface. As seen from the figure $\tau$ the maximum displacements to not vary significantly for relatively high values of the length $T$.



It is to be noted finally that the calenlation of the displacements of the alluvium layer accoriling to the Finite Element Metlod must take into consideration the elastic or anelastic properties of the alluvium consitlered and mainly its anisotropic strenght, witl the best possible accuracy. On figures 6 , in the slatied regions the curves which are not influenced signifienutly by the bountary contitions of the elges $B B^{\prime}, C C^{\prime}$ (fig. 2) are sliown. It is suggested to take into account these curves during calculations for the subsoil of the region consistered.

\section{REFEREXCLS}

(1) Ausnaseys, X. X., 1970. - Faclors controlling the Eralhquake hesponse of Foundation materials. "P'ocedings of the Bril European Symposium on Earthquake Engineering", Sofia, pp. 309-317.

(2) Bursov, S. et al., 1970. - Seismio zoning of Zagreb. "Procenliugs of the 3 European Symposium on Earthquake Eurgineeriug", Sofia, एр. $95-102$. 
(3) Duakorousos, J., 1971. - General Considerations about a Microzoning Shudy and Thessaloniti as a site for sueh a shudy. Beltrad.

(3) Gataxopoulos, A. G., 1971. - Sismology. Athens.

(5) Gaus, M. P., SHELIF, M. A., 1972. - Zonation and Microsonation. "Proceedings of the Jntermational Conference on Miorozonation", Washington, Seattle, 1 .

(6) JDrtes, 1. M., SEeI, II. B., 1967. Response of Eorth Banlis during

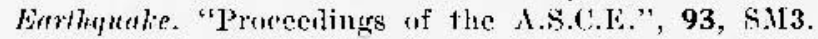

(7) Kaxa, K., 1960. - Improted Empirical Formula for the Charactoristics

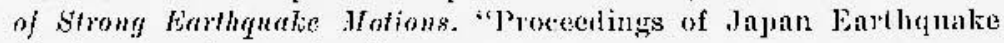
Enginecring Sy+ujukium".

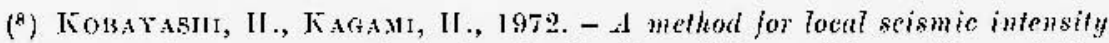
zoning mops on the basis of subsoil conditions. "P'rorecelings of the International conference on Mierozonation", Washington, Seattle, II, יני $513-528$.

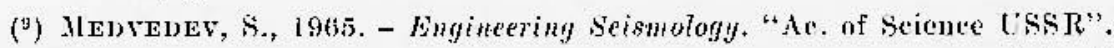

(10) P'srastanatiou, D. J., 1971. - Groum motion and response of Earh. structures subjected to strong Erathquales. Pl. 1). Thesis lmperial Colletre, Iamilon.

(11) SEEn, II. B3., 19137. - Slope stability during Earthquake. "l'roceedings of the A.S.C.E.", 93, SII4.

(12) STEFanou, G., 1970. - 1 n experimental and theoretical investigation into the perforated zones for nuclea reator pressure vessels. l'h. D. Thesis, Imperial collegre, Lomion.

(13) Stelmexsox, W. R., 1971, - Seismic Hicrowoning in Tew Zealend. "Bulletin of the New Zealant, Society for Earthquake Engineerintrg", 4, 1, March.

(14) Wu, T. IL, 1967. - Soil Mechtmies. Allyn and Bacon, Jne, Baston. 